\title{
SQUID 磁束計による生体磁場計測
}

1. SQUID 磁束計

\author{
葛西直子 \\ 電子技術総合研究所 つくば市梅園 1-1-4 \\ (1991 年 7 月 15 日 受理) \\ Biomagnetic Measurement by SQUID Magnetometer \\ 1. SQUID Magnetometer \\ Naoko KASAI \\ Electrotechnical Laboratory, 1-1-4 Umezono, Tsukuba 305 \\ (Received July 15, 1991) \\ The recent development of SQUID system for biomagnetic study is remarkable. The high sensi- \\ tive SQUID system makes possible to study the brain function and the research for the application \\ of biomagnetic measurement to the diagnosis is in progress. In this review, the techniques for mea- \\ suring the weak magnetic fields emanating from active positions in a human body are described and \\ the estimation of source location of the biomagnetic field is described. The SQUID sensor, magnetically
}

\section{Synopsis:} shielded room, reduction of magnetic noise and multi-channel SQUID systems are presented.

\section{1. はじめに}

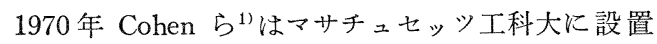
された磁気シールドルームの中で, SQUID（超伝導量 子干渉素子 : Superconducting Quantum Interference Device）磁束計を用いて明瞭な心蔵からの磁波形（心 磁図，MCG：Magnetocardiogram）を検出すること に成功した。1960年代からフェライトコアの誘導コ イルを用いて生体磁場の検出が試みられていたが22, 生体から発生される磁場（生体磁場）は弱く, 超伝導 の性質を利用した磁束感度の高いSQUID の開発に よって初めて生体磁場計測による生体機能研究の可能 性が開けたといえる。その後, SQUID の高感度化と ともに生体磁場計測は展開してきた ${ }^{3 \sim 5)}$

生体磁場計測は1) 非接触, 非侵襲計測である, 2 ) 磁場源の位置推定が可能であるという特徵をるっ ていることから, 脳機能6 9), 心蔵の機能 ${ }^{10,11)}$ や神経 系の研究などに利用されている5)。脳に捛けるさらに 高次の機能の研究も進められている。また機能異常の 診断や機能異常部位の推定を行い医療に利用する試み がなされている ${ }^{12 \sim 15)}$ 。脳機能の測定例や医学応用に ついては, 山本による医学者の立場からの解説を参照
に焦点をあてて述べる。

\section{2. 生体磁場}

\section{1 生体磁場}

人が発生する生体磁場は二つに大別される。一つは 体内に蓄積された磁性体が発生する磁場, 他の一つ は神経や筋肉が興奮するとき細胞の内外に荷電粒子 $\left(\mathrm{Na}^{+}, \mathrm{K}^{+}\right)$が流れるがそれにともなって発生する磁 場である。生体内には磁場を歪ませる磁性物質はほと んどなく, 発生した磁場は歪を受けることなく体外に 伝播される。このため体周辺で非接触に生体磁場を測 定することができる。磁性体が発生する磁場は肺機 能 $^{17)}$, 肝機能 ${ }^{18)}$ などの診断に用いられている。肺や肝 臓などに蓄えられた磁性体は磁気モーメントの向きが ランダムになっていることが多く，外部から磁場を印 加して向きを揃えた後, 測定することが多い。このた め測定装置は磁場印加用磁石と SQUID 磁束計から構 成されている。しかし，現在主として行われている生 体磁場計測の対象は荷電粒子による磁場で, 心臓, 脳，神経系などの機能を調べることに使われている。 これまでに測定された主な生体磁場の強さを Fig. 1 


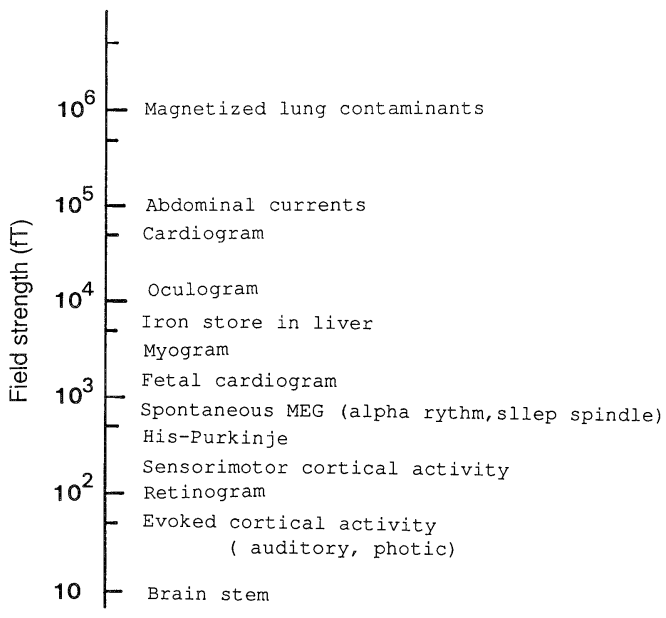

Fig. 1 Typical strength of various biomagnetic fields $\left(1 \mathrm{fT}=10^{-15} \mathrm{~T}\right)$.

に示す ${ }^{19)}$ 。Fig. 1 からわかるように, 生体磁場の中 では比較的強い心磁でも地磁気（日本では約 $3 \sim 5 \times$ $\left.10^{-5} \mathrm{~T}\right)$ の $10^{5}$ 分の 1 以下である。このように微弱な 磁場を測定するには高感度な磁束計と磁気シールド技 術の開発が必要である。Fig. 2 に主な微小磁場測定器 とその測定領域を示す。プロトン磁力計はその原理か ら直流に近い周波数領域の磁場測定のみ検出可能であ り $\mathrm{dc}$ から $1 \mathrm{kHz}$ 程度の周波数成分をもつ生体磁場測 定には適さない。フラックスゲートは感度も高く簡便 であり ${ }^{20)}$, 肺の蓄積磁性体による肺機能の研究に用い られている。

\section{2 興奮部位の位置推定}

神経や筋肉の興奮が空間的に局在して起こっている とき，それにともなって発生する磁場を計測し，磁場 源として電流双極子を仮定することによって興奮部位 を推定することができる3,4)。

無限均質媒質中に一つの電流双極子 $\boldsymbol{P}$ が座標原点

Field strength (fT)

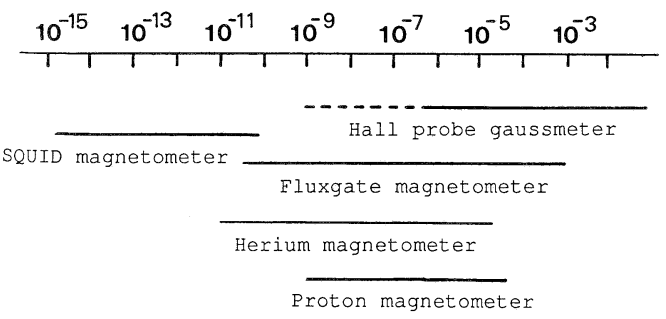

Fig. 2 Various magnetic field sensors with high sensitivity.

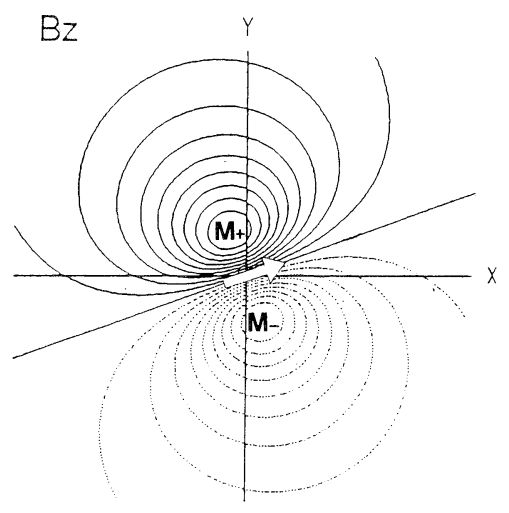

Fig. 3 Isofield contour map. The component of magnetic field $(B z)$ normal to the surface is shown as a contour map when a current dipole lies beneath the surface. The $\mathrm{M}+$ and $\mathrm{M}$ - are the maximum and minimum points. The distance between $\mathrm{M}+$ and $\mathrm{M}-$ is $\sqrt{2} d$, where $d$ is the depth of the dipole. The arrow shows the direction of the dipole.

にあるとき点 $\mathrm{Q} （ \boldsymbol{r})$ での磁束密度 $\boldsymbol{B}$ は式（1）で表 される。

$$
\boldsymbol{B}(\boldsymbol{r})=\frac{\mu}{4 \pi} \frac{\boldsymbol{P} \times \boldsymbol{r}}{|\boldsymbol{r}|^{3}}
$$

電流双極子が $x y$ 面内に向いているとき $z=d$ の $x y$ 面 に扣壮る磁場の $z$ 方向成分 $B z$ の分布は Fig. 3 のよ うになる。ここでは磁束密度が等しい点を結んだ等磁 束密度線図で表されている。このような図を等磁図と 呼んでいる。 $B z$ の極大点と極小点は電流双極子の真 上から $d / \sqrt{2}$ の距離にあり, 極大点と極小点を結ぶ 直線は電流双極子の向きと直交している。また極值は

$$
B z(\max )=-B z(\min )=0.385\left(\mu P / 4 \pi d^{2}\right)
$$

となる。ここで $\mu$ は媒質の透磁率である。生体内物質 では $\mu$ は活ぼ真空透磁率と等しく, $\mu_{0}=4 \pi \times 10^{-7} \mathrm{H} / \mathrm{m}$ であると考えて良い。このことから，体周辺において 測定面に垂直な磁場成分の等磁図が得られれば電流双 極子の大きさ，向きと位置が推定できる。しかし，電 流双極子が $z$ 軸方向を向いている場合には（1）式か ら常に $B z=0$ となる。つまりこの方法では電流双極 子の測定面に平行な成分のみが推定できる。

生体内の物質は汪とんど導電体や誘電体である。こ のため細胞が興奮したとき, 細胞内のみでなく細胞外 にも電流が流れる。この電流は体積電流と呼ばれる。 
当然体積電流も磁場を発生する。体積電流を磁場源位 置推定のモデルにどのように取り入れるかは問題であ る。電磁気理論が適用できる無限均質媒質モデル, 球 体モデル（均質, 不均質), 半無限平面モデルについ

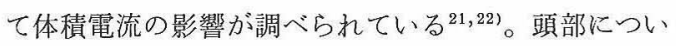
ては球体モデル，胸部については半㫶限平面モデルが 適用されることが多い。

位置推定精度については MRI 画像との重㸚合わせ や解剖学的, 生理学的知見との比較などによって研究 が進められている。Yamamotoらは, 頭部形状をし た容器に生理食塩水を満たし, 中に電流双極子を設置 したファントムを用いて， $3 \mathrm{~mm}$ 以内の精度で位置推 定を行っている ${ }^{23)}$ 。位置推定において生体磁場の測定 精度とともに重要なことは, 測定時の検出コイル位置 の位置決め精度である。これには实験室座標系と被験 者に属する座標系の変換精度も含まれる。

\section{SQUID 磁束計}

\subsection{SQUID}

SQUID には超伝導リングの一部に 1 個のジョセフ ソン素子をはめ込んだ rfSQUID と,リングの 2 カ所 に 1 個ずつ 2 個のジョセフソン素子をはめ込んだ $\mathrm{dc}$ SQUID がある ${ }^{24)}$ 。従来ジョセフソン素子の制作が困 難であったために先に開発された dcSQUID よりも rfSQUID の開発が進み, 技術的にも完成された $\mathrm{rSQ}$

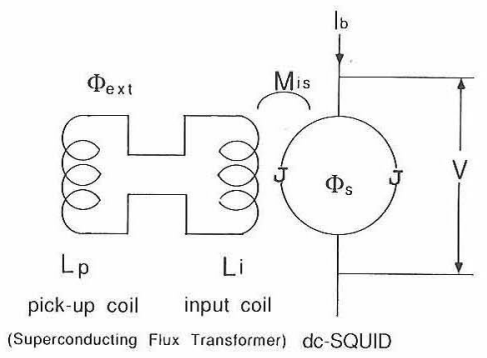

Fig. 4 Flux transfomer and dcSQUID. Flux transformer is a closed superconducting circuit. It is composed of a pickup coil and an input coil. J: Josephson junction, $I_{\mathrm{b}}$ : bias current, $V$ : output voltage of SQUID. When a magnetic flux $\phi_{\text {ext }}$ is applied to the pickup coil, the flux $\phi_{\mathrm{s}}$ is transported to the SQUID via the input coil. $\phi_{\mathrm{s}}=\left(M_{\mathrm{is}} / L_{\mathrm{i}}+L_{\mathrm{p}}\right) \quad \phi_{\mathrm{ext}}$, where $M_{\text {is }}$ is a mutual inductance between input coil and SQUID and $L_{\mathrm{i}}$, $L_{\mathrm{s}}$ are self inductance of input coil and SQUID respectively.
UID 磁束計が数社から市販されている。しかし素子 作成技術の進歩とともに rfSQUID よりる雑音特性が 優れている dcSQUID の開発が盛んに行われるように なった。数少ないが dcSQUID も市肘されるよらにな ってきているが, 素子の信頼度は rfSQUID に比べて 悪いのが現状である。しかし，より弱い脳磁を計測し たいといら要求から, 現在使用されている生体磁場計 測システムの多くは dcSQUIDを採用している。

SQUID は磁束感度が非常に高いが生体磁場を検出 するには一般には磁場が鎖交する SQUID リングの 面積が小さく（通常 $100 \times 100 \mu \mathrm{m}^{2}$ 程度）, SQUID 単 体では磁束感度は十分であるとはいえない。このため 超伝導磁束トランスを用いて磁場を濃縮する。外部磁 場と結合するコイルを検出コイル（pick-up coil），検 出した外部磁場を SQUID に伝達するコイルを入力コ イル（input coil）と呼んでいる（Fig. 4)。通常 SQU ID 素子に検出コイルと入力コイルを具備したものを SQUID 磁束計と呼ぶことが多い。入カコイルや検出 コイルの作成法として, 超伝導線をボビンに巻きつけ て作成する方法 ${ }^{25)}$ と基板上飞積層して作成する方法 ${ }^{26}$ がある。

薄膜型 SQUID そ执いて, SQUID 本体と入力コイ ルの結合を良くするために，幅の広い超伝導薄膜りン グの上に薄膜の入カコイルを積層するケッチン型が多 く用いられている27)。電総研で試作された平面型 $\mathrm{SQ}$ UID グラジオメータの写真を Fig. 5 に示す。写真で は SQUID と入力コイル部分が示されている ${ }^{28) 。}$

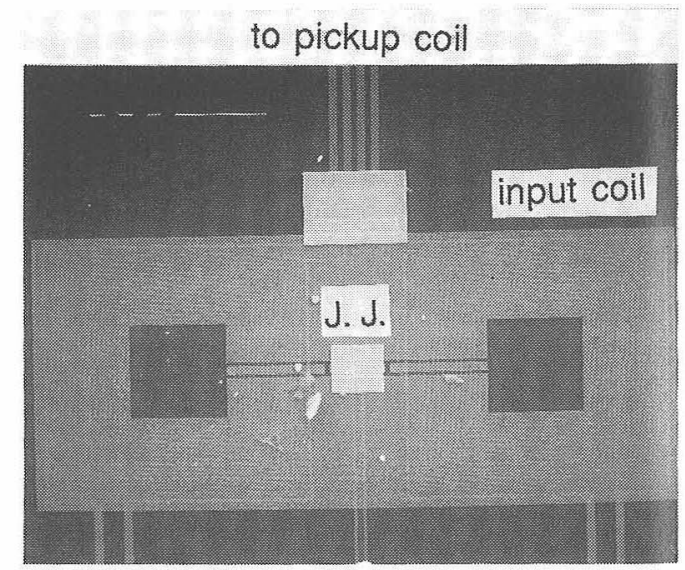

Fig. 5 Integrated dcSQUID gradiometer. The photograph shows the SQUID and the input coil integrated on the SQUID washer of an integrated dcSQUID gradiometer. ${ }^{28)}$ 
I-V Characteristic

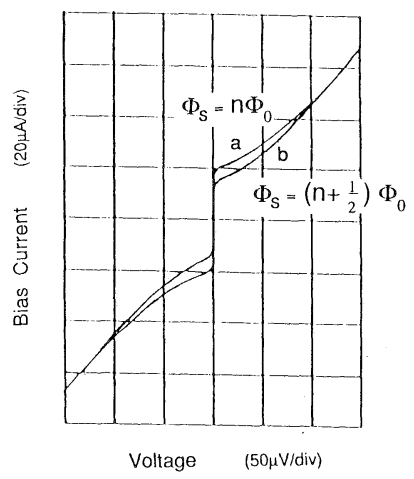

$\Phi-V$ Characteristic

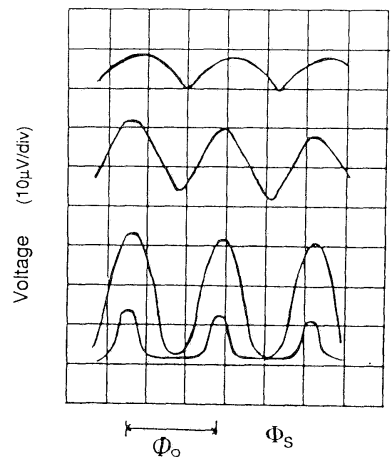

Fig. 6 (a) The current-voltage characteristics, (b) The voltage vs. signal flux characteristics. $\phi_{0}=h / 2 e\left(=2.07 \times 10^{-15} \mathrm{~Wb}\right)$. The four curves correspond to four different bias currents $I_{\mathrm{b}}$.

\section{2 動作原理と駆動法}

$\mathrm{dcSQUID}$ と rfSQUID の駆動法は異なる。 rfSQU ID の駆動には rf (radio frequency, 20 50 MHz 付 近）の周波数の電流を使用し, dcSQUID の駆動には $\mathrm{dc}$ の電流が使用される。dcSQUID と rfSQUID の命 名は駆動法の違いからきている。ここでは dcSQUID の動作原理と FLL 方式による駆動法について簡単に 述べる。

dcSQUID の電流電圧特性の例を Fig. 6 (a) と示す。 SQUID に鎖交する磁束 $\phi_{\mathrm{s}}$ が変化するとその大きさ に従って, SQUID 電圧は Fig.6 (a) 中に示した曲線 $\mathrm{a}$ と $\mathrm{b}$ の間の值をとる。ここで $\phi_{0}$ は磁束量子と呼ば れている定数で $\phi_{0}=h / 2 e\left(=2.07 \times 10^{-15} \mathrm{~Wb}\right)$ であ る。e は電子の素電荷, $h$ はプランク定数である。こ の素子に直流バイアス $I_{\mathrm{b}}$ を流して $\phi_{\mathrm{s}}$ を変化させた ときの $\phi_{\mathrm{s}}$ と SQUID の出力電圧 $V$ との関係を Fig. 6 (b) 示す。電圧 $V$ は $\phi_{0}$ の周期関数になっていること がわかる。出力と外部磁界との関係を線形化すること
と出力範囲を拡大するために，一種のゼロ位法である FLL (Flux Locked Loop) 法が用いられる。Fig. 7 に FLL 方式による dcSQUID の駆動回路の概念図を示 す。信号磁界 $\phi_{\text {ext }}$ が加わったとき, SQUID 電圧の 変動 $\delta V$ を検出し, フィードバックコイルに $\delta V$ に比 例した電流を流すことによって, 信号磁界による $\phi_{\mathrm{s}}$ と大きさが同じで逆向きの磁束を SQUID に結合さ せ，SQUID に鎖交する磁束の変動が常にゼロになる ようにする。このときフィードバックコイルに流した 電流を知ることによって外部磁束を知る方法が FLL 法である。出力電圧を高感度に検出するために, フィ ードバックコイルに変調磁場を重畳し, 位相検出を行 っている。トランスは信号増幅と同時に SQUID と前 置増幅器のインピーダンス整合の役割を担っている。

\section{4. 周辺技術}

生体磁場計測には高感度な SQUID 磁束計の開発と ともに磁気シールド技術, 冷却技術, 情報処理技術等 の周辺技術の開発が不可欠である。

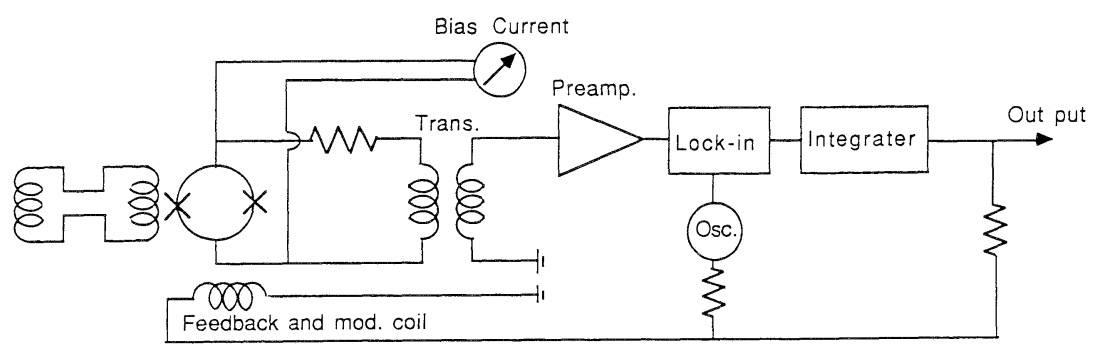

Fig. 7 Schematic diagram of the circuit for a dcSQUID system operating in a flux locked loop. 


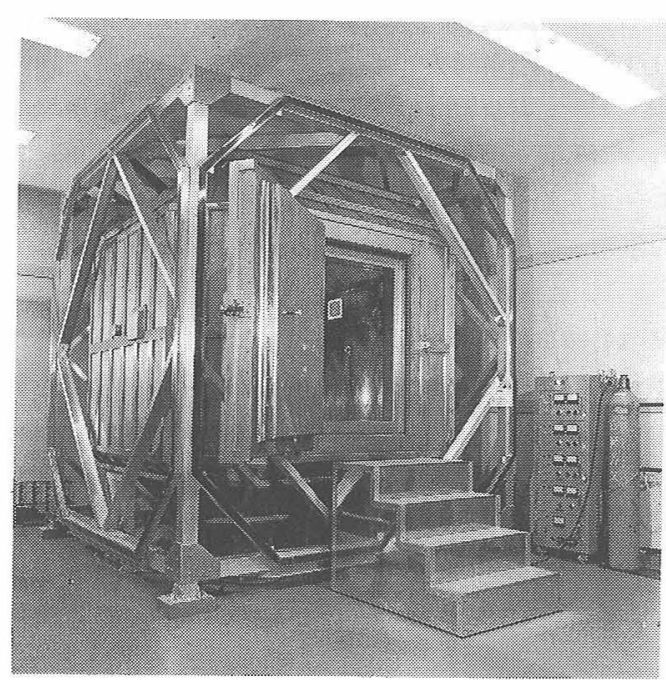

Fig. 8 Magnetically shielded room. ${ }^{30)}$

\section{1 磁気シールド技術}

生体磁場は Fig.1 に示したように微弱であるため に，地磁気を含む環境磁気雑音をいかに除去するかに よって生体磁場計測システムの最小分解能が決まる。 除去方法には1）磁気シールドルームの使用，2）検 出コイル構造の工夫，3）計算機によるディジタルフ ィルタ処理が考光られる。

従来の磁気シールドルームは高透磁率の金属を壁材 として用いることによって磁束を壁材に集中させ，シ
ールドルーム内に磁束の薄い空間を作っている29)。約 10 年前, 電総研に設置された磁気シールドルームの写 真を Fig. 8 に示す30)。このシールドルームは 3 重の 壁構造をもち, 室中心での直流残留磁気雑音は約 30 nT である。杰た遮蔽率は直流磁場に対しては $10^{3}$, $100 \mathrm{~Hz}$ 帯域では $10^{4}$ である。高次脳機能の研究や医 療への応用には，磁気ンールドルームには磁気遮蔽さ れた微小磁場空間を作るとともに，被験者へ生理的に る心理的にも圧迫を与えない空間を提供することが要 求される。

マイスナー効果により，超伝導体で囲まれた空間内 には外部の磁場変動は伝わらない。この性質を利用し て SQUID を環境磁気雑音から遮蔽するために, 超伝 導体で作った磁気シールドケースが利用されている。 最近高温超伝導体を用いて内部で生体磁場計測が可能 なシールドルームを開発する試みもなされている ${ }^{31)}$ 超伝導磁気シールドの性能は最終的に超伝導体にトラ ップされた磁束の運動で限定されると推測され，微小 磁場の空間を超伝導磁気遮蔽で奏現するには磁束トラ ップと直流残留磁場に対する十分な注意が必要であ る。

検出コイルを，Fig. 9 に示すように差動に接続する とコイルAとコイルBに鎖交する磁束は超伝導磁束卜 ランスに逆向きの遮蔽電流を作る。このためコイル $\mathrm{A}$ とコイルBに量と向きが同じ磁束が鎖交しても SQU ID には磁束は伝達されない。この原理を用いて外部

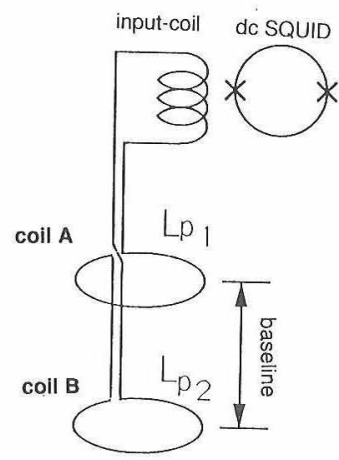

first-order gradiometer

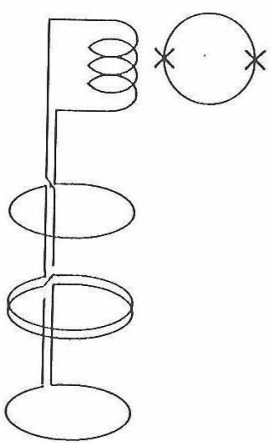

second-order gradiometer

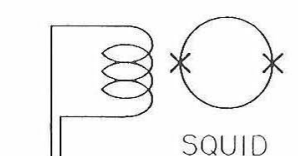

SQUID

Fig. 9 Pickup coil for gradiometer. The pickup coils in the geometry of a gradiometer are used to eliminate the magnetic noise evoked by distant sources. No shielding current flows in the flux transformer when the magnetic flux applied to the pickup coil $\mathrm{A}$ is the same as the flux to the pickup coil B. Then the magnetic flux is not transported to SQUID. 
磁気雑音の除去が行われる。磁性体または電流によっ て発生した磁界は磁気雑音源の位置からの距離 $R$ とと もに $1 / R^{2} \sim 1 / R^{3}$ で減衰する。検出コイルの位置が磁 気雑音源から十分離れている場合には磁気雑音は空間 的に一様とみなせるため, この方式で除去できる。空 間的に一様でない高次の勾配をもった磁気雑音を除去 するために種々の検出コイルが考案されている ${ }^{32}$ 。こ のような検出コイルをもつ SQUID 磁束計は検出コイ ルの次数によって 1 次微分グラジオメータ, 2 次微分 グラジオメータなどと呼ばれている。グラジオメータ による測定に拈いても，コイル A とコイル B の間隔 (ベースライン) が長い場合には信号磁界の勾配より も, 強さを検出していると考光れば良い。脳磁測定の 場合には 30 $50 \mathrm{~mm}$ 程度, 心磁計測の場合には 50 $80 \mathrm{~mm}$ 程度のベースラインが用いられて沏り, 十分長 いと考觉られる。

RF 帯域の電磁波雑音は SQUID の特性を劣化させ るため ${ }^{33)}$, 高透磁率の金属による低周波磁気雑音の遮 蔽とともに高周波雑音を遮蔽する必要がある。これに は通常アルミニウムや銅を使った電磁シールドルーム が用いられる。

\section{2 冷却技術}

現在生体磁場計測用に開発されている SQUID は二 オブ（トンネル接合部, $\mathrm{Nb} / \mathrm{Al}$-oxide/ $\mathrm{Nb}$ ) 系の材料 が用いられており, 液体へリウム中で使用されてい る。生体磁場計測には FRP デュアが用いられる。生 体磁場計測用デュアには，1）へリウムの蒸発量が少 ないこと，2）テイル部分の肉厚と真空層が薄いこ と，3）デュアそれ自体が発生する磁気雑音が少ない ことが要求される。現在のデュア磁気雑音の主な発生 源は熱遮蔽板やスーパーインシュレーション内の熱磁 気雑音であると考兄られるが34,35)，その大きさは高感 度の SQUID 本体の雑音と同程度になっている。脳磁 場の測定には条件 1) を多少犠牲にしても条件 2) と 3）を満足するデュアの開発が必要になると考兄られ る。

液体へリウムよりも取扱いの簡単な冷凍機を組み込 んだシステムが開発されている36,37)。冷凍機システム は液体へリウムを使用しないため検出コイルの設定自 由度が多く, 測定時の姿勢が限定される患者に対して は有効である。また液体へリウムの入手が困難な場所 （宇宙や野外など）での微小磁場計測の発展には閉サ イクルシステムは不可欠である。このシステムで最も 問題になるのは振動による磁気雑音（静磁場を検出コ
イルが横切るため振動に同期した磁気 雑音が発生す る）である。振動モードを検出し，計算機でディジタ ル的に除去しているが，完全に除去されてはいない。 振動の少ない冷谏機システムの開発が望まれる。

\section{3 情報処理技術}

これまで述べた磁気雑音は地磁気, 電車や自動車の 走行, 測定機器の作動などによる人工磁気雑音を想定 していた。これらの雑音の影響を磁気シールドルーム やグラジオメータの使用によってかなり低減させるこ とが可能である。しかし最近では 5.1 節でも述べるよ らに, 磁気シールドルームを含めた簡便な生体磁場計 測システムの普及が志向されている。これらのシステ ムで使用される磁気シールドルームでは遮蔽後も 10 $\mathrm{Hz}$ 以下の低周波磁気雑音が数 $10 \sim 100 \mathrm{fT} / \sqrt{\mathrm{Hz}}$ 程度 残っている。この磁気雑音を消去する方法として, 参 照用 SQUIDを用いる方法がある。信号磁場が入らぬ よらに測定用検出コイルから十分離れた所に参照用 SQUID を置き, 測定用 SQUID 出力と参照用 SQUID 出力との差をとる,つまりディジタル的にグラジオメ 一タを構成する。この方法で白色雑音は $\sqrt{2}$ 倍になる が低周波磁気雑音は低減される ${ }^{38,399}$ 。

ところで,これまで述べた方法では生体が発生する 磁気雑音は除けない。例光ば安静覚醒時に自発的に現 れる 磁波はてんかんのスパイク磁波を測定している 場合には磁気雑音となる。また心磁は強く, 頭部に打 いても十分検出され, 脳磁測定時には磁気雑音とな る。被験者の頭部に SQUID 磁束計を近づけたとき, 被験者がいなかった場合に比べて明らかに白色雑音レ ベルが増加することが実際に実験に㧊いて観測されて いる。このような磁気雑音の除去には適応フィルタの ような計算機によるディジタル処理が必要である ${ }^{40) 。 ~}$

\section{5. 多チャンネル SQUID 磁束計システム}

生体内の興奮部位を推定するには, 体周辺の多くの 点で磁場分布を測定しなければならない。1）測定時 間の軽減（被験者が患者の場合にはとくに重要であ る)，2）各測定点に打ける信号磁波の同時性の確保, のため同時に多点で測定可能な多チャンネル SQUID システムが開発されている。音や光などの刺激に対す る誘発反応脳磁界の測定に拈いても, 被験者の慣れや 疲労などの要因によって反応の強さや様子が変化する ことがある。とくに脳の高次機能になるほど他の要因 に敏感になるため, 剌激による時刻固定が可能な誘 発反応の検出にも同時に検出できる多チャンネル 
Table 1 Multi-channel SQUID system.

\begin{tabular}{|c|c|c|c|c|c|}
\hline Developed by & Country & Channel & Pickup coil & SQUID & Field sensitivity (Ref.) \\
\hline BTi & U.S.A. & $37 \mathrm{ch}$ & 1 st $\mathrm{gr}$. & dc-SQUID & $10 \mathrm{fT} / \sqrt{\mathrm{Hz}}^{41)}$ \\
\hline Sciemens & F.R.G. & $37 \mathrm{ch}$ & 1 st gr. & dc-SQUID & $20 \mathrm{fT} / \sqrt{\mathrm{Hz}}^{42)}$ \\
\hline Philips & F.R.G. & $19 \mathrm{ch}$ & $1 \mathrm{st} \mathrm{gr}$. & dc-SQUID & $15 \mathrm{f} \mathrm{T} / \sqrt{\mathrm{Hz}^{43)}}$ \\
\hline PTB & F.R.G. & $37 \mathrm{ch}$ & mag. & dc-SQUID & $5 \mathrm{fT} / \sqrt{\mathrm{Hz}}^{38)}$ \\
\hline $\mathrm{CNR}$ & Italy & $11 \mathrm{ch}$ & 1 st $\mathrm{gr}$. & dc-SQUID & $3 \mathrm{fT} / \sqrt{\mathrm{Hz}}^{44)}$ \\
\hline Helsinki Univ. & Finland & $24 \mathrm{ch}$ & planer & dc-SQUID & $3 \mathrm{fT} / \mathrm{cm} / \sqrt{\mathrm{Hz}}^{45)}$ \\
\hline
\end{tabular}

SQUID システムの使用が有効である。

\section{1 多チャンネル SQUID システム}

主な多チャンネル SQUID システムの性能と特徴を Table 1 亿示す ${ }^{38,41 ~ 45)}$ 。現在日本国内で稼働してい る多チャンネル SQUID システムは BTi 社 ; 37 チャ ソネルシステム（東京大学医学部, 岡崎国立生理学研 究所), BTi 社； 7 チャンネル 7 チャンネルシステ ム (NTT 基礎研究所), 島津製作所; 7 チャンネル システム (東京電機大学), BTi 社； 7 チャンネルシ ステム（德島大学医学部）などがある。BTi 社の 37 チャンネルシステムの写真を Fig. 10 に示す。従来, 磁気雑音の除去を目的に 4.1 節で述べたボビンに超伝 導線を巻いて作成した 2 次微分型コイルが多く用いら れてきたが，チャンネル数が多くなるとシステムの体 積が大さくなる，また次数の高い検出コイルを用いる と位置推定の際に愦差を生じやすくなる等の理由から 現在は，簡便な磁気シールドルーム+ 1 次微分グラジ オメータからなる多チャンネルシステムを使用するの が主流である。多チャンネルシステムの開発において
どこまでチャンネル数を增やせば十分であるか，議論 されているが，さらにチャンネル数と検出可能範囲を 桩大することが必要であると実感している研究者は多 い。

\section{2 多チャンネル SQUID システムへの試み}

現在開発されている 37 チャンネル SQUID システ ムよりもさらに多くのチャンネル数をもった SQUID システムの開発を行うために，いくつかの試みがなさ れている。

1） SQUID 素子の低雑音化, 高感度化: 入力コイル を含めた SQUID 素子内の共振モードのダンピン $\eta^{46 \sim 48)}$ 。超伝導薄膜の磁束トラップの低減 ${ }^{48,49)}$ 。 SQUID インダクタンスの減少 ${ }^{50,51) 。}$

2）素子と検出コイルの一体化：平面型グラジオメ 一タ ${ }^{52)}$ 。SQUID と検出コイルの直接結合 ${ }^{53)}$ 。

3）駆動回路の簡素化：緩和振動型 SQUID (Relaxation Oscillation) ${ }^{54)}$ 。 APF SQUID (Additional Positive Feedback) $)^{51,53)}$

4）低温系での SQUID とフィードバック回路との
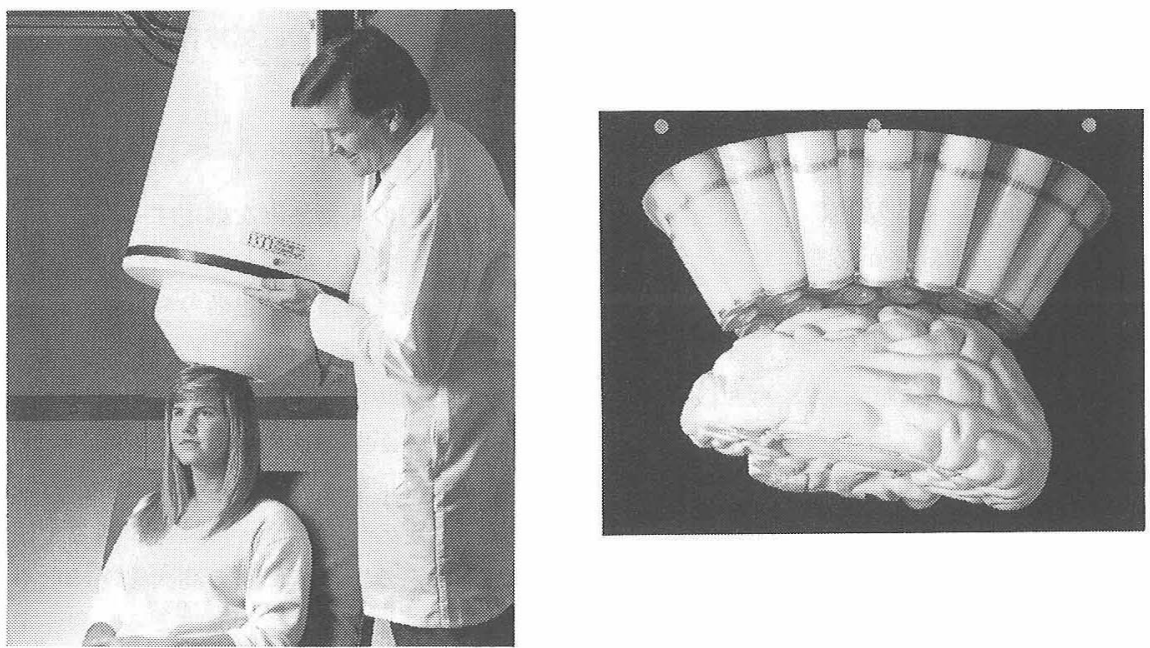

Fig. 10 The BTi 37 channel system for biomagnetic measurements. 


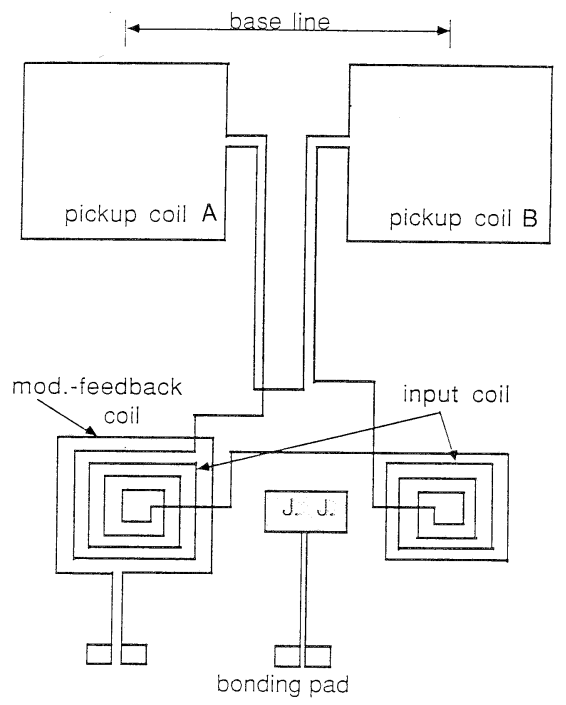

Fig. 11 Schematic of an integrated first gradiometer. ${ }^{52)}$

結合 : シングルチップ $\mathrm{SQUID}^{55)}$ 。 などの試みがなされている。

\section{3 平面型グラジオメータ}

平面型グラジオメータシステムはチャンネル数を増 加させても体積が少なくてすむメリットがある。Fig。 11 に電総研で開発された 1 次微分平面型グラジオメ 一タの概念図を示す52)。二つの検出コイルは同一平面 上に並んで置かれている。空間的に一様な環境磁気雑 音は従来型と同じく除去される。しかし信号磁場に対
するコイルAとコイルBの距離はほぼ等しくベースラ インも短いため, 従来型のように信号磁場強度を検出 するのでなく, 検出コイルの面に垂直な信号磁場成分 $B z$ の検出コイルの並んでいる方向 $x$ に対する磁場勾 配, $d B z / d x$ を検出する。このためこの検出コイル構 造をもつグラジオメータを非対角型グラジオメータと 呼ぶことがある。これに対し, 従来型を同軸型グラジ オメータと呼ぶ。1個の電流双極子による等勾配磁図 を Fig. 12 に示す56)。

\section{6. 生体磁場計測システム}

生体磁場計測システムの例を示す。Fig. 13 のシス テムは電総研に拈ける音剌激による誘発脳磁波計測の

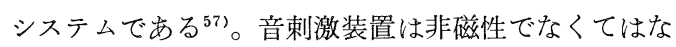
らない。ここでは圧電素子を用いた発生装置を被験者 の耳に装着して使用しているが，磁気シールドルーム から離れた場所に置かれたスピーカから空気チューブ で被験者の耳に伝達する方法が良く用いられている。 剌激音は $1 \mathrm{kHz}$ のトーンバーストで $1 \sim 5 \mathrm{~s}$ のランダ ムな持続時間の後 $1 \mathrm{~s}$ の休止時間を和いて繰り返し被 験者の耳に与えられる。SQUID 出力は low pass filter を通して計算機に集録される。その後 off line でデー 夕処理が行われる。 $\mathrm{S} / \mathrm{N}$ を良くするために 170 回程 度の加算平均が行われた。さらに雑音除去を行うため の適応フィルタを用いた。結果の例を Fig. 14 に示 す。

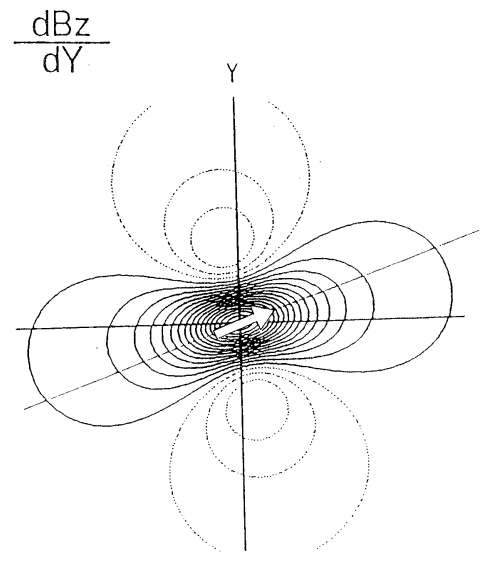

Fig. 12 Isogradient field contour map. The arrow shows the direction of the dipole. The position and direction of the dipole are estimated from the distance between poles in the map and the gradient of the line connecting the poles. ${ }^{56}$ ) 


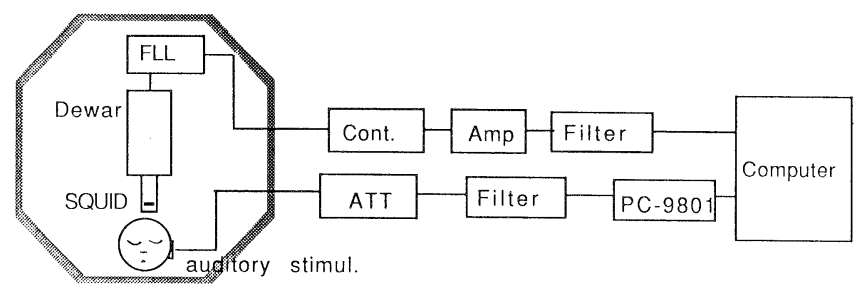

magnetically shielded room

Fig. 13 An example of the system for auditory evoked response.

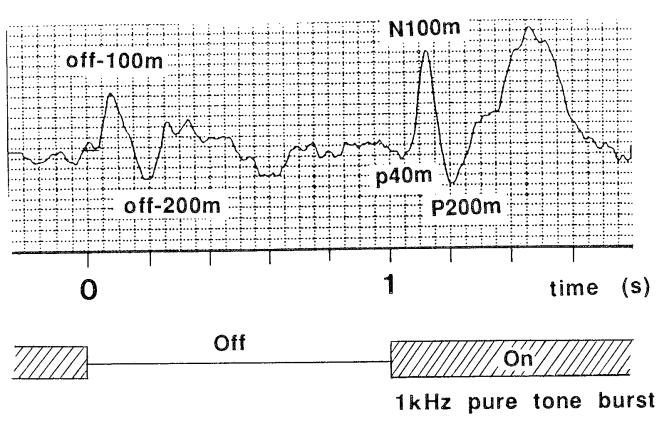

Fig. 14 Example of auditory evoked magnetoencephalogram (MEG). The on-response signals $\mathrm{P} 40 \mathrm{~m}, \mathrm{~N} 100 \mathrm{~m}, \mathrm{P} 200 \mathrm{~m}$ from auditory cortex were detected at about 40, 100 and $200 \mathrm{~ms}$ after stimulus onset and the off-response signals off $-100 \mathrm{~m}$, off- $200 \mathrm{~m}$ were detected at about 100 and $200 \mathrm{msec}$ after pause onset, respectively.

\section{7.おわりに}

SQUID 磁束計の高感度化, 多チャンネル化が進 み, 磁気シールドルームを含さ生体磁場計測システム は整備されてきたといえる。生体磁場計測は脳のメカ ニズムの研究や医療への応用が期待されているが, こ れらの研究に本格的に利用するにはいくつかの問題点 や改善点が残されている。最も大きな問題は磁場源解 析に打ける問題である。今後動物実験や多くの症例に よる計測を通して生体磁場計測の可能性が明らかにな っていくと考えている。

\section{参考文 献}

1) D. Cohen, E.A. Edelsack and J.E. Zimmerman: Appl. Phys. Lett. 16 (1970) 278

2) G. Baule and R. McFee: Am. Heart J. 66 (1963) 95

3) S.J. Williamson and L. Kaufman: J. Magn. Magn. Mat. 22 (1981) 129
4）渥美和彦，小谷 誠，上野照剛共編：バイオマ グネトロニクス入門，オーム社，東京（1986）

5) S.J. Williamson, M. Hoke, G. Stroink and M. Kotani: Advances in Biomagnetism. Plenum Press, New York (1989)

6) G.L. Romani, S.J. Williamson, L. Kaufman and D. Brenner: Exp. Brain Res. 47 (1982) 381

7) R. Hari, K. Aittoniemi, M.L. Jarvinen, T. Katila and T. Varpula: Exp. Brain Res. 40 (1980) 237

8) R. Hari, M. Pelizzone, J.P. Makela, J. Hallstrom, L. Leinonen and O.V. Lounasmaa: Audiology 26 (1987) 31

9) R.M. Chapman, R.J. Ilmoniemi, S. Barbanera and G.L. Romani: Electroencephalogr. Clin. Neurophysiol. 58 (1984) 569

10) J.P. Wikswo, J.A.V. Malmivuo, W.H. Barry, M.C. Leifer and W.M. Fairbank: Adv. Cardiovasc. Phys. 2 (1979) 1

11) B.J. tenVoorde, M.J. Peters, G. Stroink and L.R. van der Wieken: Med. Biol. Eng. Comput. 26 (1988) 130

12) D.S. Barth, W. Sutherling, J. Engle and J. Beatty: Science 223 (1984) 293

13) W.W. Sutherling, P.H. Crandall, L.D. Cahan and D.S. Barth: Neurology 38 (1988) 778

14）粟野直行, 坂内保弘, 大和田憲司, 狩米重夫 : 循環器科 22 (1987) 15

15）森 博愛, 中谷 豊, 須貝昌輝, 野村昌弘, 福 田善晴：循環器科 21 (1987) 891

16）山本智矢：低温工学 26（1991） 354

17）小谷 誠, 合原一幸, 内川義則: BME 1 (1987) 653

18) D.E. Farrel, J.H. Tripp, P.Z. Zanzucchi, J.H. Harris, G.M. Brittenham, E.M. Bellon and W.A. Muir: Appl. Phys Commun. 1 (1981) 1

19) G.L. Romani, S.J. Williamson and L. Kaufman: Rev. Sci. Instrum. 53 (1982) 1815

20) F. Primdahl: J. Phys, E: Sci. Instrum. 12 (1979) 241 
21) B.N. Cuffin and D. Cohen: IEEE Trans. Biomed. Eng. BME-24 (1977) 372

22) J. Sarvas: Phys. Med. Biol. 32 (1987) 11

23) T. Yamamoto, S.J. Williamson, L. Kaufman, C. Nicholson and R. Llinas: Proc. Natl. Acad. Sci. USA 85 (1988) 8732

24）原 宏: 量子電磁気計測, 電子情報通信学 会，（1991）第 1 章，第 4 章

25) P. Carelli, I. Modena and G.L. Romani: Biomagnetism, (ed. by S.J. Williamson, G. L. Romani, L. Kaufman and I. Modena, Plenum Press, New York (1983) Ch. 5, 85

26) M. Nakanishi, M. Koyanagi, S. Kosaka, A. Shoji, M. Aoyagi and F. Shinoki: Jpn. J. Appl. Phys. 26 (1987) 1050

27) M.B. Ketchen and J.M. Jaycox: Appl. Phys. Lett. 40 (1982) 736

28) M. Koyanagi, N. Kasai, K. Chinone, M. Nakanishi, S. Kosaka, M. Higuchi and H. Kado: IEEE Trans. Magn. MAG-25 (1989) 1166

29) A.P. Wills: Phys. Rev. 9 (1899) 193

30) S. Koga and A. Nakamura: Proc. of the 1 st Sensor Symposium (1981) 311

31）矢原昭人, 入沢大逸, 今井久美子, 松葉博則 : マグネティックス研究会資料, 電気学会, MAG90-86 (1990)

32) J. Vrba, A.A. Fiee, M.B. Burbank, H. Weinberg and P.A. Brickett: Can. J. Phys. 60 (1982) 1

33）石川 登, 葛西直子, 桐生昭吾, 佐々木広太 郎, 長田耕治, 湯田貴司 : 日本生体磁気学会誌 4 (1991) 144

34) K. Fujioka, T. Watanabe, K. Mizobuchi, K. Matumoto, T. Noda and Y. Kuraoka: Biomagnetism '87, ed. by K. Atsumi, M.Kotani, S. Ueno, T. Kattila and S.J. Williamson, Tokyo Denki University Press, Tokyo (1987) 466

35) J. Nenonen, T. Katila and J. Montonen: Advances in Biomagnetism, ed. by S.J. Williamson, M. Hoke, G. Stroink and M. Kotani, Plenum Press, New York (1989) 729

36) D.S. Buchanan, D.B. Crum, D. Cox and J.P. Wikswo: Advances in Biomagnetism, ed. S.J. Williamson, M. Hoke, G. Stroink and M. Kotani, Plenum Press, New York (1989) 677

37) G.A. Klemic, D.S. Buchanan, Y.M. Cycowicz and S.J. Williamson: Advances in Biomagnetism, ed. S.J. Williamson, M. Hoke, G. Stroink and M. Kotani, Plenum Press, New York (1989) 685

38) H. Koch, R. Cantor, D. Drung, S.N. Erne, K.P. Matthies, M. Peters, T. Ryhanen, H.J. Scheer and H.D. Hahlbohm: IEEE Trans. Magn. 27 (1991) 2793
39) M. Nakanishi, M. Koyanagi, H. Kado, N. Kasai and T. Endo: Biomagnetism '87, ed. by K. Atsumi, M. Kotani, S. Ueno, T.Kattila and S.J. Williamson, Tokyo Denki University Press, Tokyo (1987) 446

40）関田 㦑, 大津展之, 桐生昭吾, 葛西直子：日 本音響学会平成 3 年度春季研究発表会講演論文 集（1991） 355

41）金子 裕, 高倉公明：日本臨床 49 (1991) 1707

42) H.E. Hoenig, D. Daalmans, W. Folberth, H. Reichenberger, S. Schneider and H. Seifert: Cryogenics 29 (1989) 809

43) O. Dossel, B. David, M. Fuchs, J. Kruger, W.H. Kullmann and K.M. Ludeke: Abstracts of SQUID '91 (1991)

44) A. Pasquarelli, S. Casciardi, M.E. Giannini, V. Foglietti, V. Pizzella, G. Torrioli and G. L. Romani: Abstracts of SQUID '91 (1991)

45) M.S. Hamalainen: Advances in Biomagnetism, ed. S.J. Williamson, M. Hoke, G. Stroink, and M. Kotani, Plenum Press, New York (1989) 639

46) T. Ryhanen, H. Seppa, R. Ilmoniemi and J. Knuutila: J. Low Temp. Phys. 76 (1989) 287

47) H. Seppa and T. Ryhanen: IEEE Trans. Magn. MAG-23 (1987) 1083

48) V. Foglietti, W.J. Gallagher, M.B. Ketchen, A.W. Kleinsasser, R.H. Koch and R.L. Sandstrom: Appl. Phys. Lett. 55 (1989) 1451

49) G.M. Daalmans, L. Bar, F.R. Bommel, R. Kress and D. Uhl: IEEE Trans. Magn. MAG27 (1991) 2997

50) P. Carelli and V. Foglietti: J. Appl. Phys. 54 (1983) 6065

51) D. Drung, R. Cantor, M. Peters, H.J. Scheer and H. Koch: Appl. Phys. Lett. 57 (1990) 406

52）茅根一夫，葛西直子，桐生昭吾，小柳正男，賀 戸 久, 中西正和，幸坂 紳 : 電子情報通信学 会論文誌 J 73-D-11（1990）1054

53) D. Drung, R. Cantor, M. Peters, T. Ryhanen and H. Koch: IEEE Trans. Magn. MAG-27 (1991) 3001

54) S.A. Gudoschnikov, O. V. Kaplunenko, Yu V. Maslennikov and O.V. Snigirev: IEEE Trans. Magn. MAG-27 (1991) 2439

55) K. Gotoh, N. Fujimaki, H. Suzuki, T. Imamura, S. Hasuo and A. Shibatomi: extended Abstracts of Third International Superconductive Electronics Conference (1991) 148

56）葛西直子, 大海 学, 茅根一夫, 桐生昭吾, 小 柳正男, 賀戸 久: 電子技術総合研究所彙報 54 (1990) 39

57）葛西直子, 桐生昭吾, 関田 叢, 堀内竜三：日 本音響学会, 聴覚研究会資料 (1991) H-91-18 